\title{
Estimation of Weed DRy Biomass and GRain Yield as a Function of GROWTH AND Yield Traits UNDER Allelopathic WeEd MANAGEMENT IN MAIZE ${ }^{1}$
}

\author{
Estimativa de Biomassa Seca de Plantas Daninhas e Rendimento de Grãos como uma Função de \\ Características de Crescimento e Produção sob o Manejo de Plantas Daninhas Alelopáticas na \\ Cultura do Milho
}

\author{
MAHMOOD, A. ${ }^{2}$, KHALIQ, A. ${ }^{2}$, IHSAN, M.Z..$^{2,3}$, NAEEM, M. ${ }^{2}$, DAUR, I. ${ }^{3}$, MATLOOB, A. ${ }^{2}$, and \\ EL-NAKHLAWY, F.S. ${ }^{3}$
}

\begin{abstract}
Growing concerns about toxicity and development of resistance against synthetic herbicides have demanded looking for alternative weed management approaches. Allelopathy has gained sufficient support and potential for sustainable weed management. Aqueous extracts of six plant species (sunflower, rice, mulberry, maize, brassica and sorghum) in different combinations alone or in mixture with $75 \%$ reduced dose of herbicides were evaluated for two consecutive years under field conditions. A weedy check and S-metolachlor with atrazine (pre emergence) and atrazine alone (post emergence) at recommended rates was included for comparison. Weed dynamics, maize growth indices and yield estimation were done by following standard procedures. All aqueous plant extract combinations suppressed weed growth and biomass. Moreover, the suppressive effect was more pronounced when aqueous plant extracts were supplemented with reduced doses of herbicides. Brassicasunflower-sorghum combination suppressed weeds by 74-80, 78-70, 65-68\% during both years of study that was similar with S-metolachlor along half dose of atrazine and full dose of atrazine alone. Crop growth rate and dry matter accumulation attained peak values of 32.68 and $1,502 \mathrm{~g} \mathrm{~m}^{-2} \mathrm{~d}^{-1}$ for brassica-sunflower-sorghum combination at 60 and 75 days after sowing. Curve fitting regression for growth and yield traits predicted strong positive correlation to grain yield and negative correlation to weed dry biomass under allelopathic weed management in maize crop.
\end{abstract}

Keywords: Zea mays, allelopathy, crop growth indices, mulberry, plant combinations.

\begin{abstract}
RESUMO - As crescentes preocupações sobre toxicidade e desenvolvimento de resistência a herbicidas sintéticos exigiram a busca por abordagens alternativas no manejo de plantas daninhas. Alelopatia obteve apoio e potencial suficientes para o manejo sustentável de plantas daninhas. Extratos aquosos de seis espécies vegetais (girassol, arroz, amora, milho, colza ou couve-nabiça e sorgo) em diferentes combinações, isoladamente ou em mistura com $75 \%$ de redução da dose de herbicidas, foram avaliados por dois anos consecutivos em condições de campo. Uma verificação de plantas daninhas e Smetolachlor com atrazina (pré-emergência) e apenas atrazina (pós-emergência) nas doses recomendadas foi incluída para comparação. Dinâmica de plantas daninhas, índices de crescimento do milho e estimativa de rendimento foram realizados seguindo procedimentos padrão. Todas as combinações de extrato vegetal aquoso suprimiram crescimento e biomassa de ervas daninhas. Além disso, o efeito supressor foi mais pronunciado quando extractos de plantas aquosas foram suplementados com doses reduzidas de herbicidas. A combinação de colza ou couve-nabiça-girassol-sorgo suprimiu plantas daninhas em 74 - 80\%, 78 - 70\%, 65 - 68\% durante os dois anos de estudo que foram semelhantes com S-metolachlor juntamente com meia dose de atrazina e uma dose completa apenas de atrazine. A taxa de crescimento da cultura e o acúmulo de matéria seca atingiram valores máximos
\end{abstract}

1 Recebido para publicação em 26.7.2014 e aprovado em 6.10.2014.

2 Department of Agronomy, University of Agriculture Faisalabad, Pakistan, <meeransaim@gmail.com>; ${ }^{3}$ Department of Arid Land Agriculture, King Abdulaziz University, Jeddah Saudi Arabia. 
de 32.68 e $1.502 \mathrm{~g} \mathrm{~m}^{-2} \mathrm{~d}^{-1}$ para a combinação de colza ou couve-nabiça-girassol-sorgo em 60 e 75 dias após a semeadura. Regressão de ajuste de curva para as características de crescimento e produção previu uma forte correlação positiva com o rendimento dos grãos e uma correlação negativa para biomassa seca de plantas daninhas em manejo alelopático de plantas daninhas na cultura de milho.

Palavras-chave: Zea mays, alelopatia, índices de crescimento da cultura, amora, combinações de plantas.

\section{INTRODUCTION}

Maize (Zea mays) is the third important grain crop after rice and wheat in Pakistan (Abuzar et al., 2011). Maize is planted on an area of $1.12 \mathrm{~m} \mathrm{ha}^{-1}$, with an annual production of $4.52 \mathrm{~m}$ ton. It is grown under a wide range of environmental conditions due to its better adaptability. However, grain yield of maize is not to the level of potential of many of the present day cultivars of maize. Weeds are a major biological constraint, causing yield loss of up to $38 \%$ in maize (Chung, et al., 2003; Bakhtiar et al., 2011). Presently, weeds are managed by various conventional and modern approaches. Use of synthetic herbicides is very common due to their prompt response and availability (Santos, 2009; Jamil et al., 2009). Nonetheless, an indiscriminate use of herbicides is provoking various hazards related to health, ecosystem, and contamination of soil, water and aerial environment. Moreover, there are reports about the development of resistance against different herbicides as fenoxaprop-P-ethyl and mesosulfuron-methyl against wild oat, glyphosate against common ragweed and imazethapyr against common sunflower (Heap, 2008, 2014). This necessitates looking for alternative means that could help to conserve the ecosystem and sustain crop yields.

Natural plant products exhibiting phytotoxicity against weed flora, when used alone or in different combinations, are considered as a possible alternative that could minimize the hazards associated with chemical weed control. Several plants like sorghum (Sorghum bicolor), eucalyptus (Eucalyptus camaldulensis) and tobacco (Nicotiana tabacum) had already been studied for their phytotoxicity against problematic weeds in field crops. Aqueous extracts of allelopathic plants can be used for suppressing weeds in field crops (Hong et al., 2004;
Iqbal et al., 2010). Jabran et al. (2008) reported the synergistic nature of allelochemicals when applied in different combinations. This was further established by Cheema et al. (2003) who confirmed a conceivable integration of sorghum with eucalyptus and sunflower aqueous extracts. Cheema et al. (2003) proposed that mixed application of sorghum, eucalyptus and sunflower achieved $70 \%$ additional weed control than the sole application of sorghum extract in wheat. Nevertheless the level of weed control achieved with such allelopathic extracts was lower as compared with the sole use of herbicides.

The present study aimed to evaluate the phytotoxic potential of aqueous extracts of allelopathic plants as sunflower (Helianthus annuus), brassica (Brassica napus), maize (Zea mays), rice (Oryza sativa), mulberry (Morus alba) and sorghum (Sorghum bicolor) in combinations with each other and with reduced doses of synthetic herbicides. The combinations were also compared with pre- and post-emergence herbicides in terms of weed control efficacy and maize-growth indices.

\section{MATERIAL AND METHODS}

\section{Experimental site and design}

To evaluate the performance of different allelopathic plant extract combinations on weed dynamics and maize growth indices, field experiments were carried out in 2010 and 2011 at the Agronomic Research Area, of the University of Agriculture, in Faisalabad, Pakistan. The soil of the experimental area presents Aridisole fine-silty in the USDA classification and Yermosols in the FAO classification scheme, and is comprised of Lyallpur Soil Series. Electrical conductivity (EC) and $\mathrm{pH}$ of the saturation extract were $1.23 \mathrm{dS} \mathrm{m}^{-1}$ and 8.1, respectively. Maize crop was sown in the first week of August for both 
years with $70 \mathrm{~cm}$ in the row to row distance. A randomized complete block design having $8 \mathrm{~m} \times 4 \mathrm{~m}$ plot size was used with three replications. The same experimental site for both years was used where previous history exposed a massive weed invasion of several genera. Fertilizer, $150 \mathrm{~kg} \mathrm{~N}, 100 \mathrm{~kg} \mathrm{P}_{2} \mathrm{O}_{5}$ and $100 \mathrm{~kg} \mathrm{~K} \mathrm{O}_{2}$ were applied at the recommended rate.

\section{Treatments}

Plant water leachates were prepared by $24 \mathrm{~h}$ soaking of plant material in water $(1: 10 \mathrm{w} / \mathrm{v})$. Plant water extracts were further diluted and foliar sprayed after two weeks of sowing with a knapsack hand sprayer. Allelochemical treatments consisted of aqueous extracts of brassica (Brassica campestris), sunflower (Helianthus annuus), mulberry (Morris alba), rice (Oryza sativa), maize (Zea mays) and sorghum (Sorghum bicolor) in different combinations each at $15 \mathrm{~L} \mathrm{ha}^{-1}$, along with $25 \%$ of a commercial dose of atrazine. The combinations were brassica+mulberry+ sorghum, brassica+sunflower+sorghum, sunflower+rice+sorghum, sunflower+maize+ sorghum, maize+ rice+sorghum and mulberry+ sunflower+sorghum. Chemical treatments comprised S-metolachlor with atrazine at $1.08 \mathrm{~kg}$ a.i. ha ${ }^{-1}$ (pre-emergence) and atrazine alone at $0.50 \mathrm{~kg}$ a.i. ha ${ }^{-1}$ (early postemergence). A weedy check was maintained as control.

\section{Data collection}

Weed dynamics, total weed density and total weed dry biomass were recorded from two randomly selected quadrats $(50 \mathrm{~cm} \times 50 \mathrm{~cm})$ from each plot at 30, 45 and 60 days after sowing (DAS).

Maize growth indices, leaf area index (Watson, 1978), leaf area duration (LAD - days), dry matter accumulation (DMA $-\mathrm{g} \mathrm{m}^{-2}$ ) and crop growth rate (CGR - $\mathrm{g} \mathrm{m}^{-1} \mathrm{~d}^{-1}$ ) were calculated by following Hunt (1978). Agronomic and yield contributing traits were recorded by following standard procedures.

\section{Statistical analysis}

Data were analyzed for regression and correlation curve fitting, averaged over both years 2010 and 2011. Analysis of variance (ANOVA) was performed using SAS version 8.0 (E1-Nakhlawy, 2010). Least significance difference test at $\mathrm{P} \leq 0.05$ was employed to compare treatment means. Graphical representation of the data was carried out using MS-Excel. Calibration of the regression model was done to predict estimates for weed dry biomass and grain yield as a function of plant height $(\mathrm{cm})$, ear length $(\mathrm{cm})$, grain rows ear-1, grain number ear-1, 1000-grain weight $(g)$, grain-pith ratio and grain yield (t ha-1).

\section{RESULTS AND DISCUSSION}

\section{Weed dynamics}

Purple nutsedge (Cyprus rotundus), bermuda grass (Cynodon dactylon), crow foot grass (Dactyloctenum aegyptium), horse purslane (Trianthema portulacastrum), field bind weed (Convolvulus arvensis), Jungle rice (Echinochlova colona) and goose grass (Eleusine indica) were the predominant weed species in the experimental plots for both years. During both years, maximum reduction in weed density and weed dry biomass on percent bases at 30, 45 and 60 days after sowing DAS were reported where chemical herbicide combination of S-metolachlor with atrazine and atrazine alone were applied. S-metolachlor with atrazine and atrazine alone were statistically similar for weed density with brassica-sunflower-sorghum, which recorded a reduction of $74,78,65 \%$ and maize-ricesorghum combinations of $72,76,66 \%$ for the first year and brassica-sunflower-sorghum of $80,70,68 \%$ and sunflower-rice-sorghum combination of $79,63,69 \%$ for the second year at 30, 45 and 60 DAS respectively (Figure 1). Brassica-sunflower-sorghum plant extracts and maize-rice-sorghum plant extracts revealed $64,75,50 \%$ and $63,72,48 \%$ reduction in total weed dry biomass for the first year and brassica-sunflower-sorghum followed by sunflower-rice-sorghum water extracts combinations demonstrated $75,86,70 \%$ and $74,81,69 \%$ reduction for the second year at 30,45 and 60 DAS respectively. Minimum efficiency in weed control was observed in mulberry-sunflower-sorghum combination for consecutive years. 

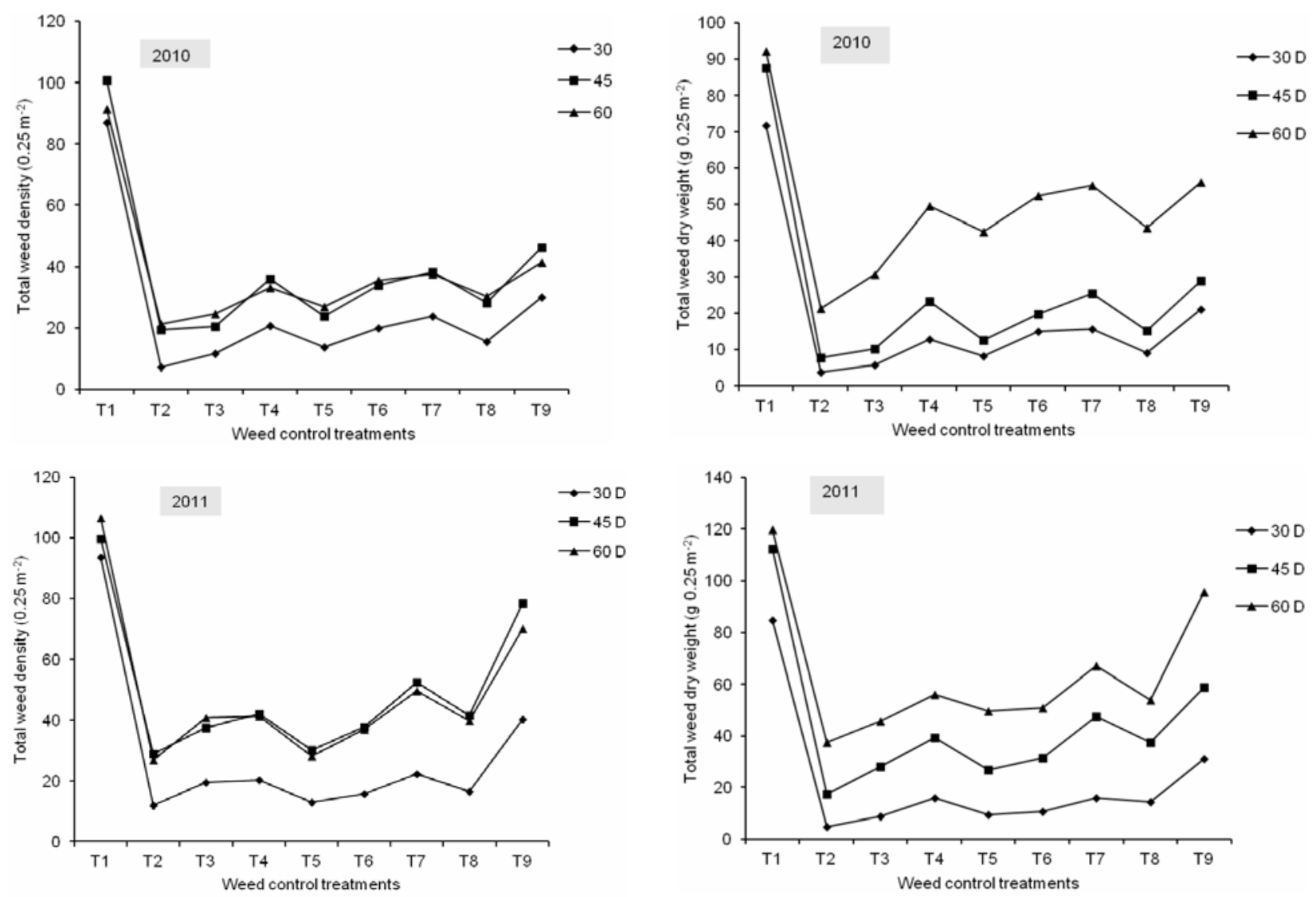

Figure 1 - Total weed density and total weed dry biomass at 30, 45, and 60 DAS for two consecutive years, 2010 and 2011 , against weed control treatments T1; weed check (control), T2; S-metolachlor with atrazine (pre-em), T3; atrazine (early post-emergence) alone, T4; brassica-mulberry-sorghum, T5; brassica-sunflower-sorghum, T6; sunflower-rice-sorghum, T7; sunflower-maizesorghum, T8; maize-rice-sorghum and T9; mulberry-sunflower-sorghum.

Our experiments revealed superior weed control by means of germination and seedling growth suppression of applied aqueous extract, in different combinations of phytotoxic plants brassica, sorghum, sunflower, maize, mulberry and rice. Suppression of weeds by plant water extracts combinations, along with reduced doses of herbicides, could be the result of higher phenolic contents, lower osmotic potential and greater electrical conductivity, along with a complex interface of allelochemicals (Ma et al., 2006). A number of allelochemicals have already been identified and reported as phytotoxic to other crops and weeds, including phenolics and flavonoids from sunflower on Phalaris minor, Chenopodium album and Coronopis didymus. Isothiocyanates and nitriles proved their worth in brassica against Phalaris minor, Avena ludoviciana, Cirsium arvense and Chenopodium album. Benzoic acid and p-hydroxy benozoic acid testified in sorghum against Chenopodium album, Parthenium hysterophorus, Rumex retroflexus and Avena sativa. Coumaric acids and ferulic acid affirmed their toxicity in rice against Echinochloa crus-galli. 5-chloro-6-methoxy-2benzoxazolinone (Cl-MBOA) and 6-methoxy-2benzoxazolinone (MBOA) were reported in maize as potentially phytotoxic against Lolium multiflorum, Amaranthus caudatus and Lactuca sativa (Alsaadawi, 2007; Macias et al., 2008).

\section{Maize growth indices}

Maize growth indices as leaf area index, leaf area duration (days), dry matter accumulation $\left(\mathrm{g} \mathrm{m}^{-2}\right.$ ) and crop growth rate $\left(\mathrm{g} \mathrm{m}^{-2} \mathrm{~d}^{-1}\right)$ were measured at $30,45,60,75$ and 90 DAS. Leaf area index and leaf area duration were gradually improved for the first 
30 DAS, then a sharp increase was observed until 60 DAS for leaf area index and 75 DAS for leaf area duration. A highest value for leaf area index (4.96-4.77) was observed at 60 DAS where S-metolachlor with atrazine was applied and was followed by LAI (4.87-4.63), where brassica-sunflower-sorghum aqueous extracts were applied for the respective years. S-metolachlor with atrazine produced maximum leaf area duration (165.52 d) for the first year and brassica-sunflower-sorghum combination (161.47 d) for the second year at 75 DAS, which were statistically nonsignificant (Figure 2).

Dry matter accumulation $\left(\mathrm{g} \mathrm{m}^{-2}\right)$ continued until crop maturity while a sharp decline in crop growth rate $\left(\mathrm{g} \mathrm{m}^{-2} \mathrm{~d}^{-1}\right)$ was assessed at 75 DAS. Dry matter accumulation of 15.02 and $13.54 \mathrm{~g} \mathrm{~m}^{-2}$ were recorded for brassicasunflower-sorghum combination for 2010 and 2011, respectively, while crop growth rate attained peak value $\left(32.68 \mathrm{~g} \mathrm{~m}^{-2} \mathrm{~d}^{-1}\right)$ for brassica-sunflower-sorghum combination at
60 DAS. It was followed by atrazine alone $\left(32.13 \mathrm{~g} \mathrm{~m}^{-2} \mathrm{~d}^{1}\right)$ for the first year while $\left(27.80 \mathrm{~g} \mathrm{~m}^{-2} \mathrm{~d}^{-1}\right)$ and $\left(26.33 \mathrm{~g} \mathrm{~m}^{-2} \mathrm{~d}^{-1}\right)$ was obtained for brassica-sunflower-sorghum and maize-rice-sorghum extract combination for the second year (Figure 3). Mulberry-sunflowersorghum aqueous extract combination presented a minimum value (2.46-2.67, 123-118, 1068-1055 and 8.06-6.47) for leaf area index, leaf area duration (days), dry matter accumulation $\left(\mathrm{g} \mathrm{m}^{-2}\right)$ and crop growth rate $\left(\mathrm{g} \mathrm{m}^{-2} \mathrm{~d}^{-1}\right)$ at 90 DAS for consecutive years. Brassica-mulberry-sorghum and maize-ricesorghum combinations yielded the least values for crop growth rate and leaf area indices.

Aqueous extracts of different plants alone or in combination with other plant extracts or a reduced dose of herbicides hampered weed growth, enhanced crop growth and improved yield up to a considerable level. Sorghum aqueous extract reduced weed density and dry biomass by $35-49 \%$, brassica achieved weed reduction up to $75-82 \%$ against winter weeds,
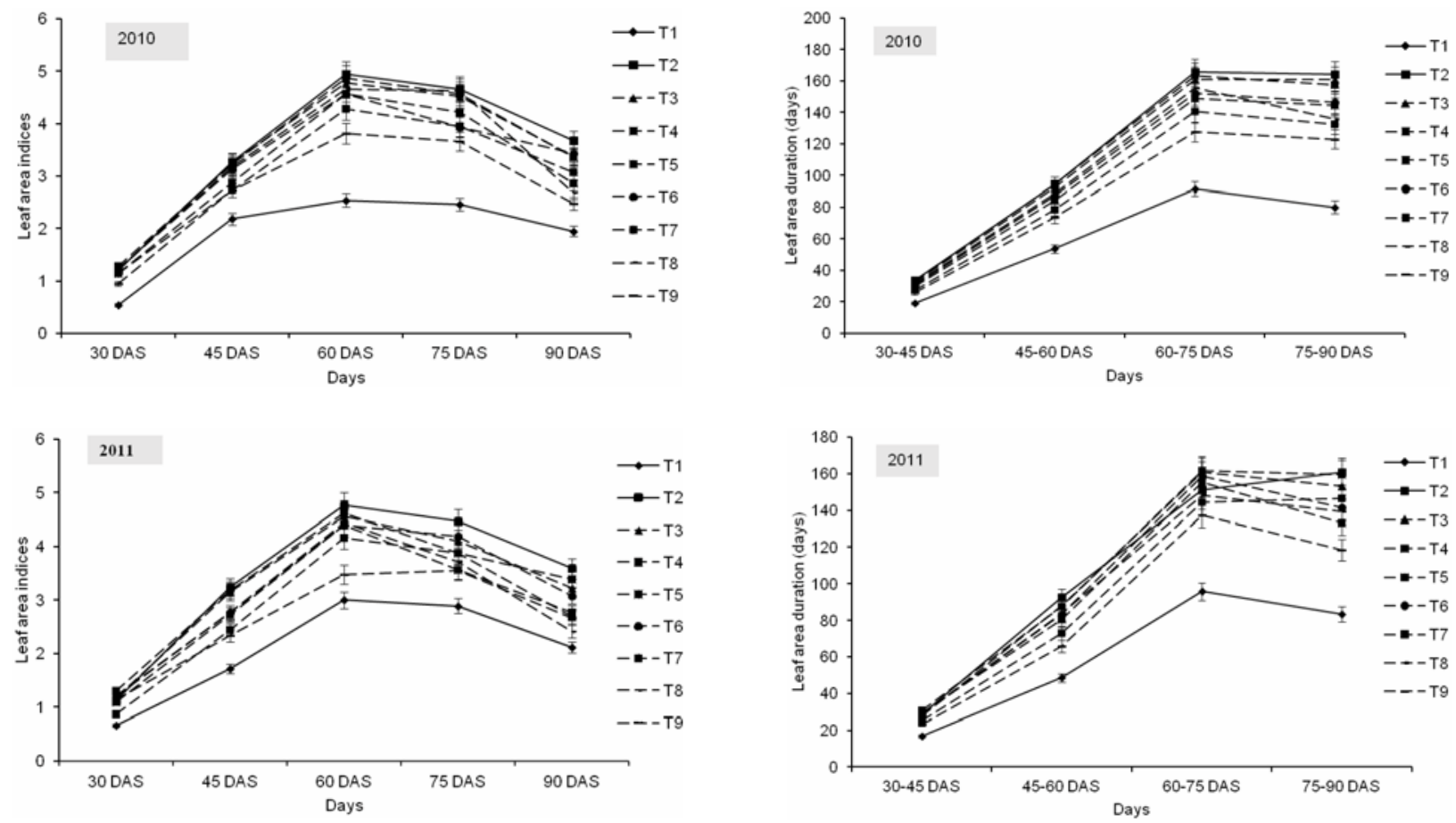

Figure 2 - Leaf area indices and leaf area duration measured at 30, 45, 60, 75 and 90 DAS for two consecutive years, 2010 and 2011, against weed control treatments T1; weedy check (control), T2; S-metolachlor with atrazine (pre-emergence), T3; atrazine (early post-emergence) alone T4; brassica-mulberry-sorghum, T5; brassica-sunflower-sorghum, T6; sunflower-rice-sorghum, T7; sunflower-maize-sorghum, T8; maize-rice-sorghum and T9; mulberry-sunflowersorghum. The bars represent the comparison of means using LSD (Least Significant Difference) test p $\leq 0.05$. 

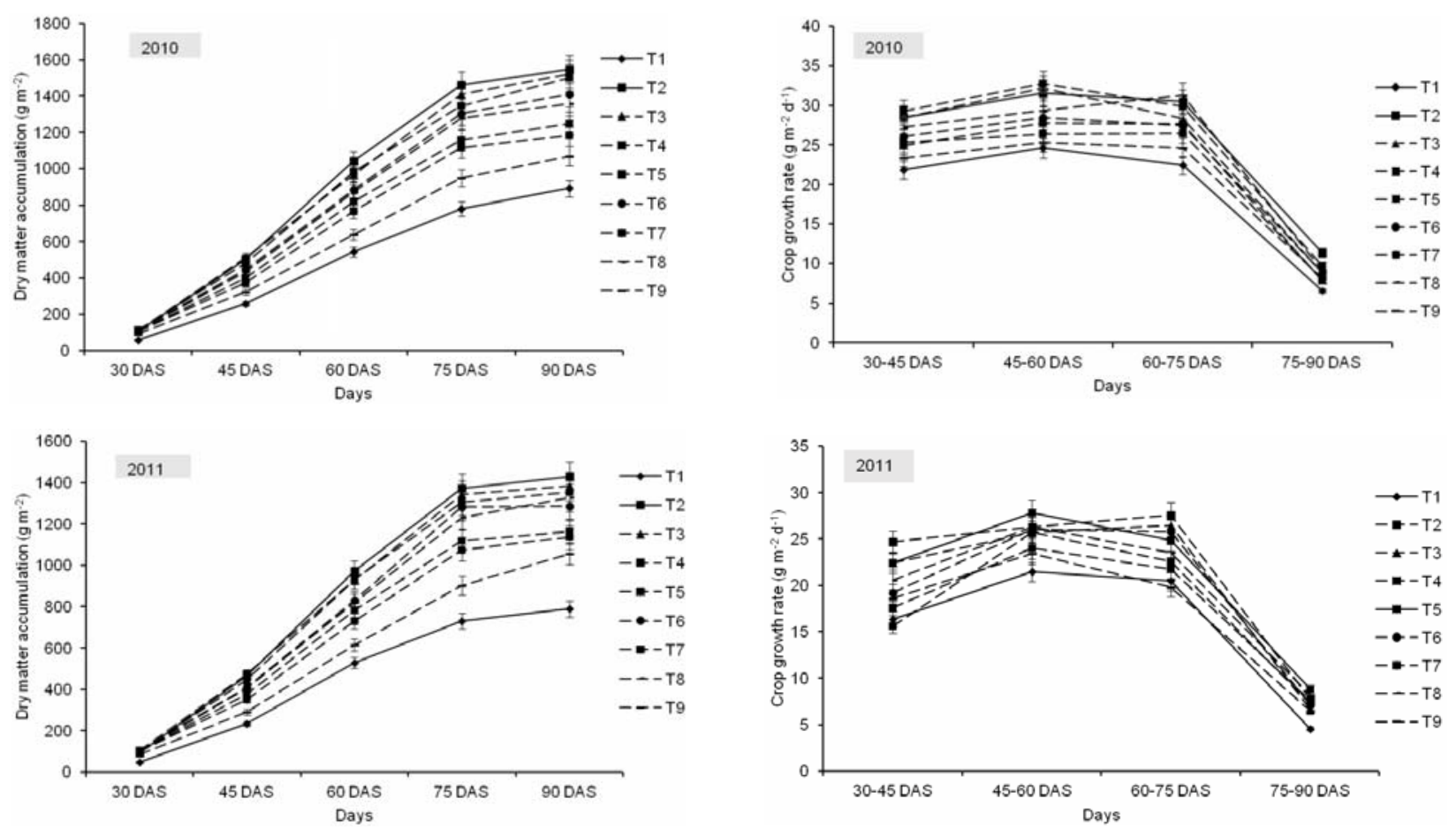

Figure 3 - Dry matter accumulation ( $\left.\mathrm{g} \mathrm{m}^{-2}\right)$ and crop growth rate $\left(\mathrm{g} \mathrm{m}^{-2} \mathrm{~d}^{-1}\right)$ measured at 30, 45, 60, 75 and 90 DAS for consecutive years, 2010 and 2011, against weed control treatments T1; weed check (control), T2; S-metolachlor with atrazine (pre-emergence), T3; atrazine (early post-emergence) alone, T4; brassica-mulberry-sorghum, T5; brassica-sunflower-sorghum, T6; sunflowerrice-sorghum, T7; sunflower-maize-sorghum, T8; maize-rice-sorghum and T9; mulberry-sunflower-sorghum. The bars represent the comparison of means using LSD (Least Significant Difference) test $\mathrm{p} \leq 0.05$.

rice straw extracts produced weed suppression $(22 \%)$ hulls $(8 \%)$ grain and $(12 \%)$ leaves (Anjam et al., 2007). Mulberry produced a significant $(73 \%)$ weed suppression when applied combined to a reduced dose of herbicides, also enhancing paddy yield by $23 \%$. The exact mechanism of action of most plants aqueous extracts is still unclear but many reports have mentioned phytotoxicity of used plant combinations in their individual capacity. A possible mechanism may involve a decreased activity of some enzymes like proteases, ureases and phosphorelases, a decline in chlorophyll content and photosynthesis, a greater cell membrane permeability and lipid metabolism (Shen et al., 2013).

Germination and growth suppression under allelopathic weed management resulted in limiting nutrient and water uptake due to disorders in normal plant processes. Consequently, favoring crop growth indices like leaf area index, leaf area duration, dry matter accumulation and crop growth rate through lessening the competition for available resources and improving yield components in maize, cob length, number of grains per cob, 1000 grain weight thus, resulted in higher stalk, and economic and biological yield (Catherine et al., 2003; Shen et al., 2013).

\section{Curve fitting regression analysis}

Regression analysis for weed dry biomass and grain yield was carried out for the pooled data of 2010 and 2011 due to a non-significant year's effect.

Estimation of dependency was performed using a simple linear regression with a trend line drawn across the variants. Weed dry biomass and grain yield variation predicted a strong correlation for most of the studied parameters. Ear length $(\mathrm{cm})$, depicted maximum value for $\mathrm{R}^{2}, 0.975$ and 0.969 for both weed dry biomass and grain yield (Figure 4). Grains per ear and grain rows per ear predicted 

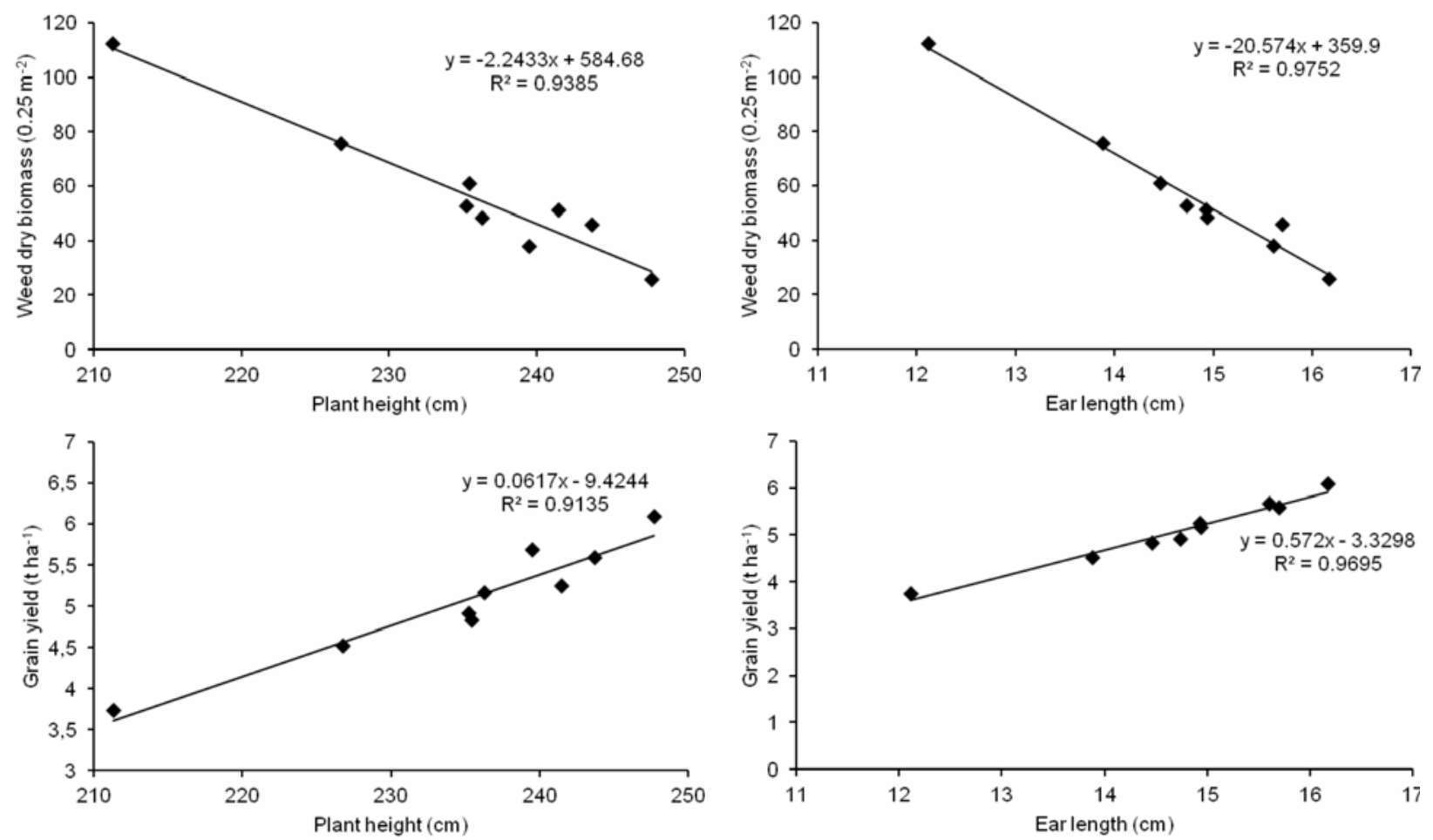

Figure 4 - Calibration of the regression model predicting weed dry biomass and maize grain yield as a function of plant height (cm) and ear length $(\mathrm{cm})$ have pooled over both years, 2010 and 2011, against weed control treatments.
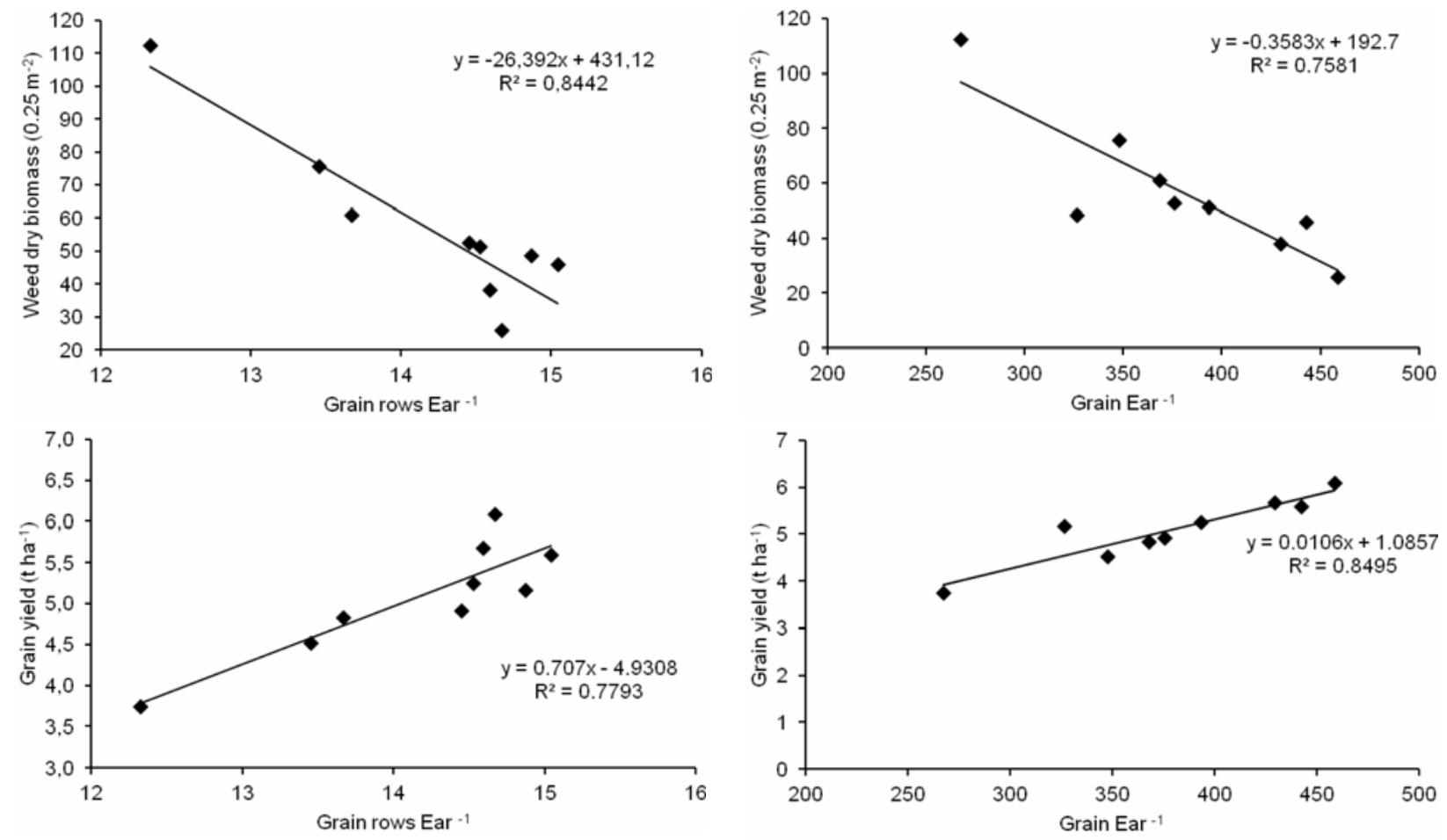

Figure 5 - Calibration of the regression model predicting weed dry biomass and maize grain yield as a function of grain rows per ear and grains per ear pooled over both years, 2010 and 2011, against weed control treatments. 

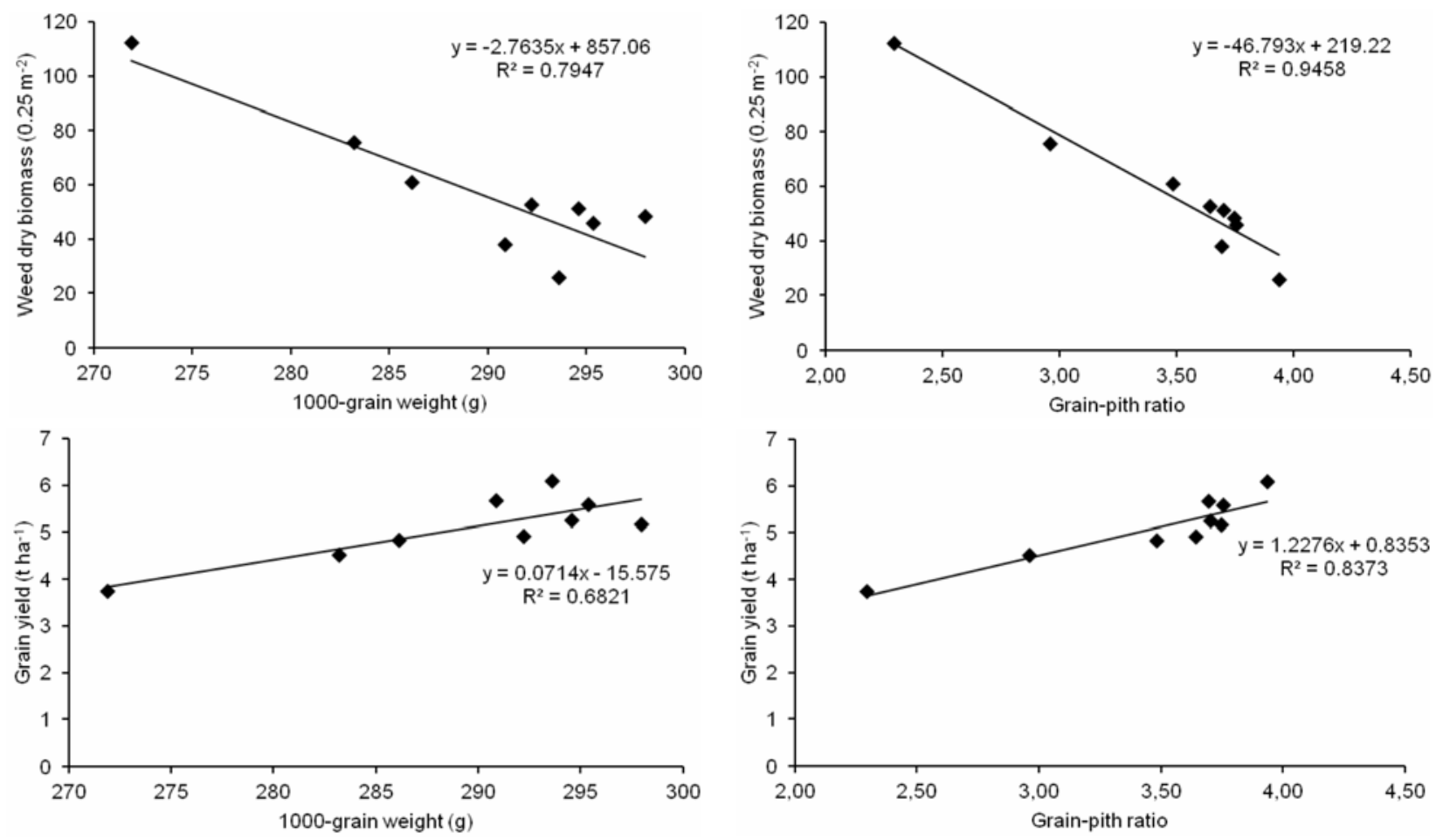

Figure 6 - Calibration of the regression model predicting weed dry biomass and maize grain yield as a function of 1000 grain weight (g) and grain-pith ratio pooled over both years, 2010 and 2011, against weed control treatments.

a medium relation with weed dry biomass and grain yield having $\mathrm{R}^{2}$ values of 0.758 and 0.779 , respectively (Figure 5). 1000-grain weight depicted a strong correlation to weed control by means of a reduction in weed dry biomass while average correlation to grain yield was observed with the predicted dispersion values of 0.794 and 0.682 (Figure 6). Moreover, all maize yield components reported a negative correlation to weed dry biomass but a strong positive correlation to grain yield.

Previous studies have also stressed on the need for development of new plant combinations with a reduced dose of herbicides for weed control at a specific crop-weed level (Cheema et al., 2003; Farooq et al., 2008). Synthetic herbicides when augmented with phytotoxic plant extracts have presented a superior weed control and a higher crop yield in relation to the sole application of herbicides. Khan et al. (2012) confirmed the role of allelopathic plant extracts by means of $70-75 \%$ weed suppression along with a reduced dose of herbicides. Moreover 47, 35 and 30\% higher grain yield were recorded, where 100, 50 and
$25 \%$ of the recommended dose of atrazine are supplemented with different phytotoxic aqueous plants combinations. The present study concluded that plant combinations brassica-sunflower-sorghum and maizerice-sorghum presented above $80 \%$ weed suppression, which equals to a sole application of synthetic herbicides. These treatments may be adopted as a suitable alternative for an efficient and eco-friendly allelopathic weed management approach in maize.

\section{LITERATURE CITED}

ABUZAR, M. R. Effect of plant population densities on yield of maize. J. An. Plant Sci., v. 21, n. 4, p. 692-695, 2011.

ALSAADAWI, I. S. Sorghum allelopathy for weed control; past achievements and future needs. intl. In: WORKSHOP ON ALLELOPATHY-CURRENT TRENDS AND FUTURE APPLICATIONS. March 18-21., Faisalabad, University of Agriculture, 2007.

ANJUM, T. Field appraisal of herbicide potential of sunflower leaf extract against Rumex dentatus. Field Crop Res., v. 100, n. 4, p. 139-142, 2007. 
BAKHTIAR, G. B. M. Impact of tillage, plant population and mulches on weed management and grain yield of maize. Pak. J. Bot., v. 43, n. 3, p. 1603-1606, 2011.

CATHERINE, M. C. Validation of a hyperspectral curve fitting model for the estimation of plant water content of agricultural canopies. Remote Sens. Environ., v. 87, n. 2, p. 148-160, 2003.

CHEEMA, Z. A. Reducing herbicide rate in combination with allelopathic sorgaab for weed control in cotton. Int. J. Agric. Biol., v. 5, n. 5, p. 1-6, 2003.

CHUNG, I. M. Comparison of allelopathic potential of rice leaves, straw, and hull extracts on barnyard grass. Agron. J., v. 95, n. 6, p. 1063-1070, 2003.

EL-NAKHLAWY, F. S. Experimental design and analysis in scientific research. Sci. Pub. Center., v. 8, n. 3, p. 122-127, 2010.

FAROOQ, M. Allelopathic effects of rice on seedling development in wheat, oat, barley and berseem. Allelop. J., v. 22, n. 2, p. 385-390, 2008.

HEAP, I. Herbicide resistant weeds. Int. Pest Manag., v. 3, n. 1, p. 281-301, 2014.

HEAP, I. The international survey of herbicide resistant weeds. online internet. Dec. 02, 2008. Available online: $<$ http://www.weedscience.com>. 2008.

HONG, N. H. Paddy weed control by higher plants from South East Asia. Crop Protec., v. 23, n. 4, p. 255-261, 2004.

HUNT, R. Plant growth analysis. London: Edward Arnald, 1978. 37 p.
IQBAL, I. Response of wheat crop (Triticum aestivum L.) and its weeds to allelopathic crop water extracts in combination with reduced herbicide rates. Pak. J. Agric. Sci., v. 47, n. 3, p. 309-316, 2010.

JABRAN, K. Tank mixing of allelopathic crop water extracts with pendimethalin helps in the management of weeds in canola (Brassica napus) field. Intern. J. Agric. Biol., v. 10, n. 4, p. 293-296, 2008.

JAMIL, M. Alternative control of wild oat and canary grass in wheat fields by allelopathic plant aqueous extracts. Agron. Sustain. Develop., v. 29, n. 3, p. 475-482, 2009.

KHAN, M. B. Allelopathic plant water extracts tank mixed with reduced doses of atrazine efficiently control Trianthema portulacastrum L. in Zea mays L. J. An. Plant Sci., v. 22, n. 4, p. 339-346, 2012.

MA, H. J. Allelopathic potential of K21, selected as promising allelopathic rice. Weed Biol. Manag., v. 6, n. 2, p. 189-196, 2006.

MACIAS, F. A. Helikauranoside A, A new bioactive diterpene. J. Chem. Ecol., v. 34, n. 1, p. 65-69, 2008.

SANTOS, B. M. Drip-applied metam potassium and herbicides as methyl bromide alternatives for Cyperus control in tomato. Crop Protec., v. 28, n. 1, p. 68-71, 2009.

SHEN, X. Chemical control of weedy rice in precise hilldirect-seeded rice in south china, Weed Biol. Manag., v. 13, n. 1, p. 39-43, 2013.

WATSON, R. N. Argentine stem weevil control in maize. In: NEW ZEALAND WEED AND PEST CONTROL CONFERENCE, 31., 1978, New Plymouth, Proceeding... New Plymouth, 1978. p. 96-102. 